as irregular is, in view of the parallel passages which have been adduced by $\mathrm{me}^{1}$ and not disputed by any scholar, now impossible. i, 28 is wholly different, and if the reading is correct is a real case of nominative form used for accusative. Now, if Mr. Pargiter will investigate usage, he will find that he can parallel from the later Vedic and epic periods a case like hetavah as acc., but he will search in vain for a parallel to parolsşolkta bhrātaras trayah. But Mr. Pargiter's argument is not to be regretted, however wrong. He contends that Māgadharājāno bhavitāro vadāmi te is not Sanskrit, but is Pali, and that the dynastic account was therefore not originally written in Sanskrit. He finds a precise parallel in the Brhaddevatā, iv, 32. This fact can be interpreted in one way only: either we must admit a Pali original of the Brhaddevata, which no competent scholar will ever do, or we must admit that Mr. Pargiter's argument in the case of the dynastic account is wrong. There is no escape from this dilemma.

A. Berriedale Keith.

\title{
THE ZOROASTRIAN PERIOD OF INDIAN HISTORY
}

Dr. Spooner having invited me to make some observations on the proof of his second paper, I have the pleasure to comply briefly with his request. Full discussion of his somewhat daring speculations would require a book.

I agree with the proposition (p. 71) that "Persian influence in early India is no hypothesis at all". It is a fact, to which I drew attention so far back as 1905 (Ind. Ant., 1905, p. 201). Whether or not the Maurya dynasty was one "of almost purely Persian type" (p. 72) may be considered doubtful in the present state of the

1 JRAS. 1909, pp. 430-2, and Speyer there cited. So also in Greek, Kühner-Gerth, ii, 353, 354. The quotation of commentators (above, p. 516, n. 2) as authorities for grammatical usages is of no value whatever. 
evidence. Dr. Spooner's papers add considerably to that evidence, and he may prove to be right. I think he has proved that the Kumrähār building on which he is at work was copied from a Persepolitan original.

It is better for me to say nothing about the etymological speculations, with which professed philologists are more competent to deal. Punch-marked coins (p. 411) come within my province. I dealt with the subject at considerable length in the Indian Museum Catalogue, 1906, which does not seem to have been in Dr. Spooner's hands when he wrote the essay to which he refers, published in 1909. He now (p. 412) identifies the branch symbol with the Zoroastrian hom. Formerly he took it to represent the Buddhist bodhi tree. Symbolism assumes such an infinite variety of meaning that either interpretation, or both interpretations, may be right. Perhaps, the hom allusion is the more probable.

As to the so-called chaitya (caitya) symbol, the use of the term goes back to James Prinsep (Essays, ed. Thomas, $i, 214)$. It is prominent on Andhra coins besides the classes named by Dr. Spooner (p. 413). He states that Mr. R. D. Banerji tells him that this device is used as a symbol "of a certain Tirthankara", and is still designated by the Jains as "Mount Meru". He does not name the Tirthankara, but probably he is Neminatha, to whom the Girnār mountain is peculiarly sacred (Stevenson, Notes on Modern Jainism, Blackwell, Oxford, 1909, p. 52). The shrine of Neminatha is the largest and perhaps the oldest temple on Girnār. I cannot find any trace of the identification of Girnār with Mount Meru.

I am disposed to agree with Dr. Spooner that the caitya symbol is a conventional representation of a hill. The punch-marked coins sometimes show a peacock perched on it. The interpretation as a hill seems to suit all classes . of coins. The symbol is often associated with a curved line, presumably meaning a river. 
I am now much inclined to believe that many of the symbols on the early coins were intended to refer to the Jain religion, which probably is older than the Buddhist. The rhinoceros is especially significant. It occurs on Nos. 48, 58, and 59 of my I. M. Catalogue (p. 132, pl. xix, 5,6). The animal is the emblem of Śreyāmsanātha, the eleventh Tirthankara, and does not seem to be used as a symbol by either Buddhists or Brahmanical Hindus.

The dog on the caitya (Theobald, p. 212, fig. 49, in JASB., part i, vol. lix, 1890) suggests either Zoroastrian or Tibetan influence. I may remark in passing that there was much more of the latter in ancient India than is generally recognized.

The reference to Jain symbols on coins leads me to observe that speculations about the origin of primitive Buddhism, by which I mean "Buddhism before Buddha", cannot be dissociated from consideration of Jainism, which may well be still older.

Dr. Spooner boldly affirms (p. 429) that "Chandragupta [Candra-] was a Parsi", and (p. 453) that "Buddha was a Persian". Again, he states that "Buddhism ... stands for the spiritual acclimatization of a section of the domiciled Iranians" (p. 455). Those propositions need examination which cannot be atternpted now. I only utter the caution that the Jain problem is closely associated with the Buddhist one. A great mass of tradition connects the early kings of Magadha, whether Śaisunāga, Nanda, or Maurya, with Jainism.

VinCent A. SMith.

\section{MALAVA-GANA-STHITI}

This will be, I hope, my last contribution to this unprofitable discussion, in which, indeed, I would not have taken part at all, but that Dr. Thomas, in starting it, ${ }^{1}$

${ }^{1}$ JRAS. 1914, p. 413. 